Foss. Rec., 22, 119-123, 2019

https://doi.org/10.5194/fr-22-119-2019

(C) Author(s) 2019. This work is distributed under

the Creative Commons Attribution 4.0 License.

\title{
On the first Silis Charpentier, 1825 from Baltic amber (Coleoptera, Cantharidae)
}

\author{
Francesco Parisi ${ }^{1,2}$ and Fabrizio Fanti ${ }^{3}$ \\ ${ }^{1}$ Dipartimento Agricoltura, Ambiente e Alimenti, Università degli Studi del Molise, Via De Sanctis, 86100 Campobasso, Italy \\ ${ }^{2}$ GeoLAB - Laboratorio di Geomatica Forestale, Dipartimento di Scienze e Tecnologie Agrarie, Alimentari, \\ Ambientali e Forestali, Università degli Studi di Firenze, Via San Bonaventura 13, 50145 Florence, Italy \\ 3 independent researcher: Via del Tamburino 69, 53040 Piazze, Siena, Italy
}

Correspondence: Francesco Parisi (francesco.parisi@unimol.it)

Received: 30 August 2019 - Revised: 21 October 2019 - Accepted: 21 October 2019 - Published: 15 November 2019

\begin{abstract}
Only in recent years have new genera and species of the subfamily Silinae Mulsant, 1862 been described as inclusions in amber. However, no representative of the genus Silis Charpentier, 1825 had been described from Baltic amber, even if few specimens were already known at the generic level. Silis lombardii sp. nov. is entirely dark brown and shows (as usual for the genus) the two characteristic lobes in the sides of pronotum, elongated elytra, and a basal small tooth only on the anterior claws. The Eocene findings show that the subfamily is of ancient origin and that at least in the Eocene it was much more abundant than today in the same territories, where only two species are known. (urn:lsid:zoobank.org:act:768871273D24-41DA-86CC-7DCAB40DC3B7)
\end{abstract}

\section{Introduction}

The subfamily Silinae Mulsant, 1862 is widespread with a very high number of species in the eastern Palaearctic, Africa, South America and South-East Asia (Delkeskamp, 1939, 1977; Kazantsev and Brancucci, 2007; Constantin, 2010), but it is very poor in genera and species diversity in the western Palaearctic and Europe. Biodiversity hotspots appear to be former Indo-China, Indonesia and South America, even if the systematic knowledge at the generic level is still to be studied in depth (Ramsdale, 2002) for many regions and in particular for the Oriental region and North America. Also noteworthy is the fact that no species of the subfamily has reached southern Australia, Tasmania and New Zealand (Delkeskamp, 1977; Ramsdale, 2002). Recently, three extinct genera probably related to Silis and a species of the genus Autosilis Kazantsev, 2011 have been described from Baltic amber (Kazantsev, 2013; Alekseev and Kazantsev, 2014; Fanti and Damgaard, 2018; Fanti and Pankowski, 2018). Concerning the genus Silis Charpentier, 1825 in fossil records, the species Silis chiapasensis has been described from Miocene Mexican amber (Wittmer, 1963), and few specimens are known at the generic level for Eocene Baltic amber (Klebs, 1910; Bachofen-Echt, 1949; Fanti, 2017). These findings denote and suggest an ancient presence in Europe (Fanti and Damgaard, 2018) starting at least from the Eocene (no representative of the Silinae subfamily is currently known from the Cretaceous), and with a strong current rarefaction due to causes unknown to date. With the exception of S. mingrelica (Kazantsev, 1994) from Georgia, only another species, i.e. S. ruficollis (Fabricius, 1775), is currently present and widespread in Europe including the Baltic region (Kazantsev and Brancucci, 2007).

\section{Material and methods}

The amber piece was cleaned, polished and comes from a Yantarny mine in the Sambian Peninsula, Russia. The inclusion was photographed with a Zeiss AxioCam ICc 3 digital camera mounted on a Zeiss Stemi 2000c-stereomicroscope, with the addition of focus stacking software Helicon Focus, and with a Nikon D3100 digital camera equipped with AF$\mathrm{S}$ DX Micro-Nikkor lens (40 mm f/2.8G). Figures were then processed and produced using PhotoImpact Viewer SE. Measurements were taken with an ocular micrometer mounted on a Leica S8APO microscope. The material is deposited 
in the University of Molise (Unimol), Italy, under accession code Unimol AAA003FP (AAA denotes Department of Agricoltura (agriculture), Ambiente (environment) and Alimenti (foods); 003 denotes the sequential number; FP denotes the Francesco Parisi collection).

\section{Systematic paleontology}

Family Cantharidae Imhoff, 1856

Subfamily Silinae Mulsant, 1862

Tribe Silini Mulsant, 1862

Genus Silis Charpentier, 1825

Subgenus Silis Charpentier, 1825

Silis (Silis) lombardii sp. nov.

(Figs. 1-3)

\section{Description}

Adult, winged, male-defined on the basis of the long antennae and elongate lateral lobes of the pronotum. Body length: $5.2 \mathrm{~mm}$, elytra: $3.9 \mathrm{~mm}$, antennae: around $3.2 \mathrm{~mm}$. Entirely dark brown.

Head large, as wide as pronotum, slightly rugose, little exposed being partially covered by pronotum. Eyes elliptical and protruded, inserted in the upper and lateral part of the head. Maxillary palpi 4-segmented, unequal in length with the last palpomere very elongate and securiform. Labial palps 3-segmented with the last palpomere securiform. Antennae inserted near the eyes, just reaching the metafemora, 11-segmented, filiform, all antennomeres covered with small setae; scape elongate and enlarged, clubshaped; antennomere II (pedicel) extremely short and globular; antennomeres III-IV longer than antennomere II, robust; antennomere V slightly longer than antennomeres III-IV; antennomeres VI-IX slender and longer than antennomere $\mathrm{V}$; antennomere $\mathrm{X}$ slightly shorter than antennomeres VIIX; antennomere XI filiform, oblong with rounded apex. Pronotum slightly elongate, surface undulating with concavities and small setae and punctuation; apical margin convex; sides posteriorly expanding, with two elongated and apically pointed long processes: the posterior processes are sinuous and with a small basal acute tooth and the anterior ones are slender and straight. Scutellum triangular. Elytra wider than pronotum with slightly rugose microsculpture and some setae; elongate and covering the last abdominal segments; enlarged at humeri and narrow in the middle; apex strongly rounded. Posterior wings almost completely covered by elytra. Metasternum very elongate with rounded posterior margin, abdominal segments transverse and rugose. Legs long, slender and pubescent; coxae short
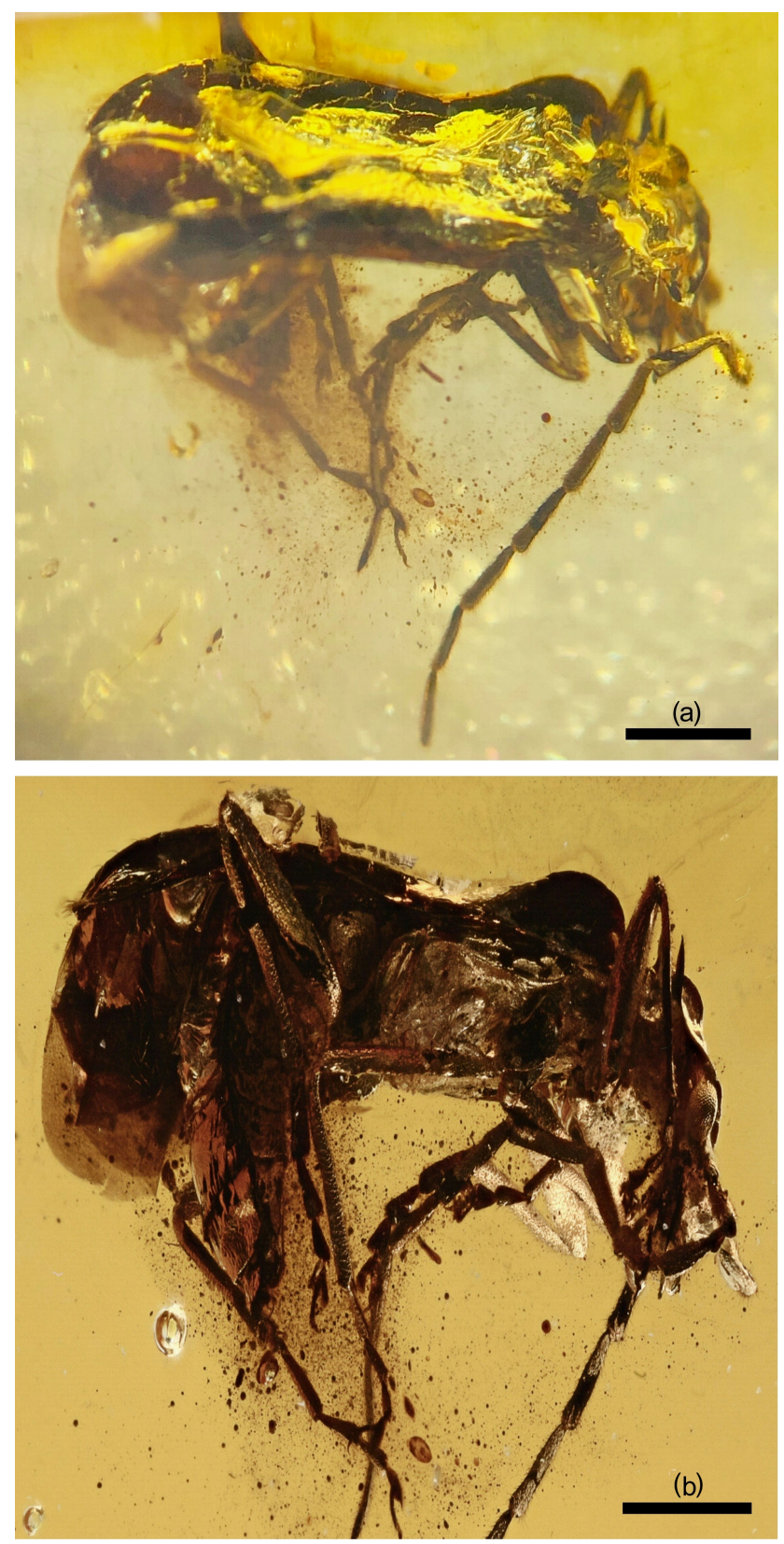

Figure 1. Silis (Silis) lombardii sp. nov. in Baltic amber, holotype. (a) Dorsal view, scale bar $=1.0 \mathrm{~mm}$. (b) Ventral view, scale bar $=1.0 \mathrm{~mm}$.

and robust; trochanters elongate and triangular-shaped with rounded apex; femora enlarged and slightly curved; tibiae cylindrical, shorter than femora, with an apical spur. Tarsal formula 5-5-5; first tarsomere elongate and slightly enlarged apically; second shorter than first; third tarsomere triangular and shorter than tarsomere II; fourth tarsomere deeply bilobed at sides; fifth tarsomere very elongate, slender, flat and curved; proclaws with an obtuse basal tooth, meso- and metaclaws simple without basal tooth. Female unknown, sexual dimorphism is supposed. 

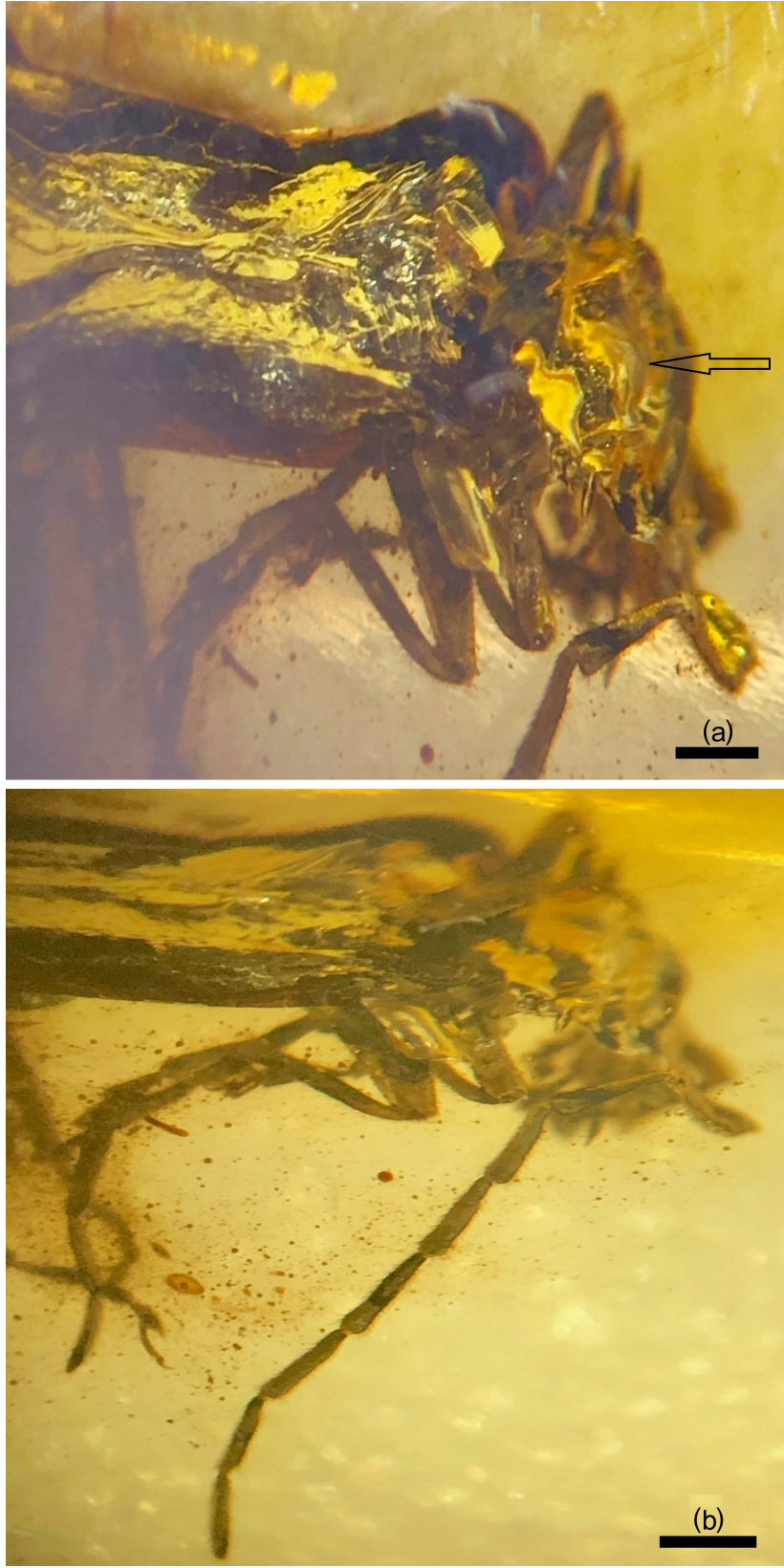

Figure 2. Silis (Silis) lombardii sp. nov. in Baltic amber, holotype. (a) Detail of pronotum (arrow), scale bar $=0.4 \mathrm{~mm}$. (b) Detail of right antenna, scale bar $=0.4 \mathrm{~mm}$.

\section{Etymology}

Named in honour of Fabio Lombardi (Department of Agricultural Science, Mediterranea University of Reggio Calabria, Italy), dear friend and colleague of the first author.

\section{Holotype}

Male, in Baltic amber, deposited at the University of Molise (Unimol) with accession no. Unimol AAA003FP.
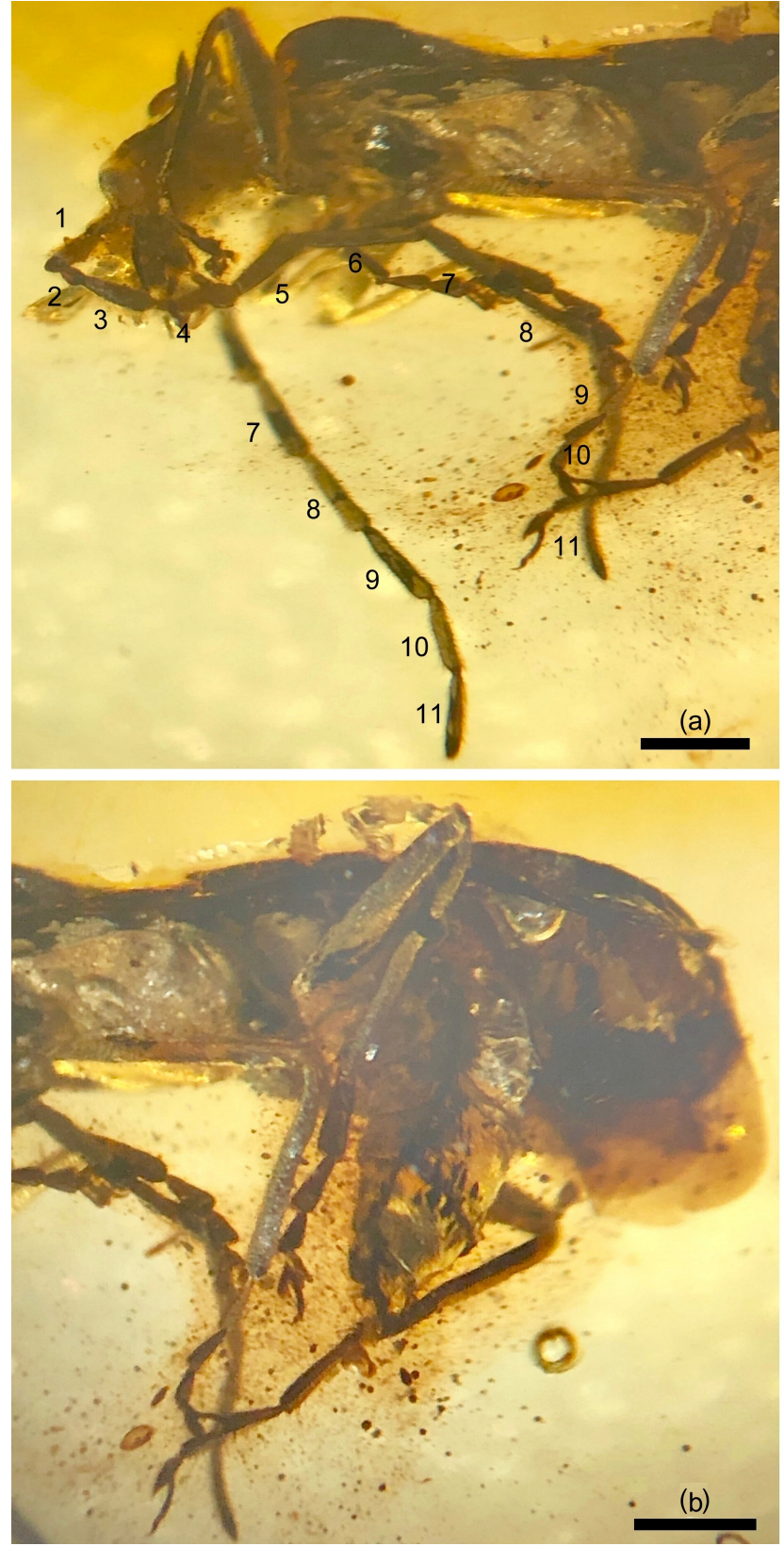

Figure 3. Silis (Silis) lombardii sp. nov. in Baltic amber, holotype (a) Detail of pronotum (ventral view), elytra, legs and antennae with numbered antennomeres, scale bar $=0.5 \mathrm{~mm}$. (b) Detail of last abdominal segments (lateral view), scale bar $=0.5 \mathrm{~mm}$.

\section{Type locality}

Yantarny mine, Sambian Peninsula, Kaliningrad region, Russia.

\section{Type horizon}

Middle Eocene (Lutetian) (47.8-41.2 Myr) to Late Eocene (Priabonian) (37.8-33.9 Myr). 


\section{Syninclusions}

Air bubbles and debris (botanical remains).

\section{Remarks}

The amber piece is flat and elongate and measures approximately $18 \mathrm{~mm} \times 6-8 \mathrm{~mm}$. The inclusion is complete and well visible. The specimen is crumpled but not damaged.

\section{Systematic placement}

Maxillary palpi sub-equal in length with last palpomere securiform, elytra elongated, abdomen with only eight visible urites, protarsal claws with small tooth, meso- and metatarsal claws simple, and pronotum laterally with two long lobes in each part clearly make this new species belonging to the subfamily Silinae and to the genus Silis (Brancucci, 1980; Constantin, 2010, 2017).

\section{Differential diagnosis}

Silis lombardii sp. nov. differs from S. chiapasensis Wittmer, 1963 (Mexican Chiapas amber) in a slightly larger size, darker colour, and different shape of pronotum and lateral processes (Wittmer, 1963). Silis lombardii sp. nov. differs from the extant $S$. ruficollis in the body colour (S. ruficollis is black with red pronotum), the smaller size (5.2 instead of 6-7.5 $\mathrm{mm}$ in S. ruficollis) and in the more elongate lateral lobes of the pronotum.

\section{Discussion}

In temperate and northern Europe the genus Silis composes species of plains, rarely of higher altitudes, particularly present on shores of lakes or on marshy meadows (Moscardini, 1972). These habitats were typical in the Baltic Eocene, where no evident orogenetic events were reported (Sadowski, 2017). Thus, Silis is considered herein a hygrophilous genus and of temperate climate. Elsewhere, the genus Silis appears more thermophilic, since it is very frequent in the tropics (Constantin, 2010, 2017) suggesting that Silis can be paraphyletic. The elevated temperatures and the extreme environmental variety evidently favour the diversification and the evolution of the Silinae; for this reason, in Eocene amber many more species could be found again in the future. The thermal gradient and the subtropical environment present during the Eocene (Weitschat and Wichard, 2010; Sadowski et al., 2017) may, however, have played an important role in their spread in the Baltic area. The decrease in temperatures and annual precipitation at the end of the Eocene and continued in the Oligocene (Weitschat and Wichard, 2010) reduced the number of taxa in northern temperate zones of Europe.

However, for example in the temperate zones of North America there is a higher number of species than in $\mathrm{Eu}-$ rope (Arnett Jr., 1963; Green, 1966; Ramsdale, 2002). In contrast with Europe the biodiversity centre is in montane regions, particularly in California (Ramsdale, 2002). This fact suggests, rather, a Trans-Beringian Pliocene spread of temperate-cold species, as for example the fossil Opsimini (Coleoptera Cerambycidae) from Baltic amber (Vitali and Damgaard, 2016). The oldest finds of the Silinae subfamily are the species included in Baltic amber to which an Eocene species, as adpression, from fossiliferous deposits of Florissant, Colorado, USA (Wickham, 1914; Fanti, 2017), and an undescribed specimen from the argillaceous limestone of the Tertiary strata (Eocene or Oligocene) of Aixen-Provence, France (de Serres, 1843; Pictet, 1854; Fanti, 2017), are added. However, a much older evolution of the subfamily, referable to the Cretaceous as it is for the subfamily Cantharinae (Fanti, 2017), is hypothesised.

Data availability. The material included in the paper is accessible in the Department of Agricultural, Environmental and Food Sciences of the University of Molise (Unimol), Italy, and all data are included in the description.

Author contributions. Both authors contributed equally to the article.

Competing interests. The authors declare that they have no conflict of interest.

Acknowledgements. We are grateful to Fabio Lombardi (Department of Agricultural Science, Mediterranea University of Reggio Calabria, Italy) for the constant scientific support.

Review statement. This paper was edited by Torsten Scheyer and reviewed by Francesco Vitali and one anonymous referee.

\section{References}

Alekseev, V. I. and Kazantsev, S. V.: New fossil soldier beetle (Coleoptera: Cantharidae) from Baltic amber, Baltic Journal of Coleopterology, 14, 167-170, 2014.

Arnett Jr., R. H.: The beetles of the United States (A manual for identification), Catholic University of America Press, Washington, D.C., xi + 1112 pp., 1963.

Bachofen-Echt, A. F.: Der Bernstein und seine Einschlüsse, Springer-Verlag, Wien, 204 pp., 1949.

Brancucci, M.: Morphologie comparée, évolution et systématique des Cantharidae (Insecta: Coleoptera), Entomologica Basiliensia, 5, 215-388, 1980.

Constantin, R.: A contribution to the genus Silis Charpentier, 1825, in Ecuador (Coleoptera, Cantharidae), Entomologica Basiliensia et Collectionis Frey, 31, 55-87, 2010. 
Constantin, R.: Les Silinae de Guyane avec la description de quatorze espèces nouvelles (Coleoptera, Cantharidae), Contribution à l'étude des Coléoptères de Guyane, 11, 41-67, 2017.

de Charpentier, T.: Horae entomologicae, adjectis tabulis novem coloratis, A. Gosohorsky, Wratislaviae, xvi + 255 pp., 1825.

Delkeskamp, K.: Pars 165: Cantharidae, in: Coleopterorum Catalogus, edited by: Junk, W. and Schenkling, S., Dr. W. Junk Verlag für Naturwissenschaften, 's-Gravenhage, 357 pp., 1939.

Delkeskamp, K.: Pars 165 (I): Cantharidae, in: Coleopterorum Catalogus Supplementa, edited by: Wilcox, J. A., Dr. W. Junk bv. Publishers, The Hague, 485 pp., 1977.

de Serres, P. M. T.: Notes géologiques sur la Provence, Actes de la Société Linnéenne de Bordeaux, 13, 1-82, 1843.

Fabricius, J. C.: Systema entomologiae, sistens insectorum classes, ordines, genera, species, adiectis synonymis, locis, descriptionibus, observationibus, Korte, Flensburi et Lipsiae, xxxii +832 pp., 1775.

Fanti, F.: Catalogo Cantharidae fossili del mondo, Fossils \& Minerals Review, 2, 1-18 (abbreviated Italian version), World catalog of fossil Cantharidae, Fossils \& Minerals Review, 2, 1-52 (extended English version), 2017.

Fanti, F. and Damgaard, A. L.: Fossil soldier beetles from Baltic amber of the Anders Damgaard amber collection (Coleoptera: Cantharidae), Baltic Journal of Coleopterology, 18, 1-32, 2018.

Fanti, F. and Pankowski, M. J.: A new fossil soldier beetle (Coleoptera, Cantharidae, Silinae) from Eocene Baltic amber, Zootaxa, 4370, 189-193, 2018.

Green, J. W.: Revision of the Nearctic species of Silis (Cantharidae: Coleoptera), Proceedings of the California Academy of Sciences, 32, 447-513, 1966.

Imhoff, L.: Versuch einer Einführung in das Studium der Koleoptern. In zwei Theilen und einem 25 Tafeln lithographirter Abbildungen nebst Text enthaltenden Anhange, Schweighauser, Basel, xxxi + [2]+114+[2]+ 272 pp., 1856.

Kazantsev, S. V.: The Palaearctic species of the genus Silis Charpentier, 1825 with the description of Crudosilis gen. n. (Coleoptera: Cantharidae), Elytron, 8, 93-115, 1994.

Kazantsev, S. V.: Errata for Volume 4 (pp. 28-32), in: Catalogue of Palaearctic Coleoptera, edited by: Löbl, I. and Smetana, A., Vol. 7. Curculionoidea I, Apollo Books, Stenstrup, 373 pp., 2011.

Kazantsev, S. V.: New taxa of Baltic amber soldier beetles (Insecta: Coleoptera: Cantharidae) with synonymic and taxonomic notes, Russian Entomological Journal, 22, 283-291, 2013.

Kazantsev, S. V. and Brancucci, M.: Cantharidae, 234-298, in: Catalogue of Palaearctic Coleoptera, edited by: Löbl, I. and Smetana, A., Vol. 4, Elateroidea, Derodontoidea, Bostrichoidea, Lymexyloidea, Cleroidea, Cucujoidea, Apollo Books, Stenstrup, 395 pp., 2007.
Klebs, E. H. R.: Über Bernsteineinschlüsse im allgemeinen und die Coleopteren meiner Bernsteinsammlung, Schriften der Physikalisch-ökonomischen Gesellschaft zu Königsberg in Preußen, 51, 217-242, 1910.

Moscardini, C.: Revisione dei Cantaridini europei (Coleoptera, Malacodermata): generi Podabrus, Cratosilis, Pseudocratosilis, Silis, Bollettino del Museo di Zoologia dell'Università di Torino, 8, 177-216, 1972.

Mulsant, É.: Mollipennes. Histoire naturelle des Coléoptères de France, Magnin, Blanchard \& Cie., Paris, 4+440 pp., 1862 (reissued in: Annales de la Société Linnéenne de Lyon (N.S.), 9, 57-496, 1863).

Pictet, F. J.: Traité de Paléontologie ou histoire naturelle des animaux fossiles considérés dans leurs rapports zoologiques et géologiques (Seconde Édition, revue, corrigée, considérablement augmentée, accompagnée d'un atlas de 110 planches grand in$4^{\circ}$ ), Tome Deuxième, J.-B. Baillière, Paris, 727 pp., 1854.

Ramsdale, A. S.: Family 64. Cantharidae Imhoff 1856, 202-218, in: American Beetles, 2. Polyphaga: Scarabaeoidea through Curculionoidea, edited by: Arnett Jr., R. H., Thomas, M. C., Skelley, P. E., and Frank, J. H., CRC Press, Boca Raton, Florida, xiv +861 pp., 2002.

Sadowski, E.-M.: Towards a new picture of the "Baltic amber forest" - flora, habitat types, and palaeoecology, Thesis, Göttingen, v+319 pp., 2017.

Sadowski, E.-M., Schmidt, A. R., Seyfullah, L. J., and Kunzmann, L.: Conifers of the "Baltic amber forest" and their palaeoecological significance, Stapfia, 106, 1-73, 2017.

Vitali, F. and Damgaard, A. L.: Dicentrus mehli sp. n. (Coleoptera: Cerambycidae) implies close trophic association between Opsimini and Calocedrus, dating the Baltic amber back to the Early Oligocene, Baltic Journal of Coleopterology, 16, 37-43, 2016.

Weitschat, W. and Wichard, W.: Baltic amber, in: Biodiversity of fossils in Amber from the major world deposits, edited by: Penney, D., Siri Scientific Press, Manchester, 1-304, 2010.

Wickham, H. F.: New Miocene Coleoptera from Florissant, Bulletin of the Museum of Comparative Zoölogy at Harvard College, in Cambridge, 58, 423-494, 1914.

Wittmer, W.: A new cantharid from the Chiapas amber of Mexico, University of California Publications in Entomology, 31, 53), 1963. 